\title{
Introduction: \\ Reframing Cinematic Space and Audience Practice in the Digital Age
}

DR DARIO LLINARES, University of Brighton

and

DR SARAH ARNOLD, Falmouth University

\section{KEYWORDS}

Spectatorship, Cinema, Digital Culture, Film History, Dispositif 
In 1930, The Chelmsford Chronicle reports on the rowdy audiences that have been the cause of much trouble and concern. A manager gives an account of deviant audience practices whereby they seem most unruly and disruptive during those very good, quality films. According to the article these audiences spoil the entertainment and betray their ignorance of good drama (23 ${ }^{\text {rd }}$ May, 9). In 1937, D.V. Weeks, a patron of a Portsmouth cinema implored his fellow picture-goers to refrain from conversing for the duration of the picture. Romeo and Juliet - the movie - had been interrupted by nattering, much to his dismay. His letter to the Portsmouth Evening News was expressive of a certain high culture elitism, he was indeed 'disgusted' that 'some of the finest lines ever written' were obscured by laughter and shouting. He speculated that some were ignorant of the work and appealed "to those people who do not like fine and wholesome acting to stay away" (28 ${ }^{\text {th }}$ April 1937, 3). What might this reflect about the 'appropriate' behaviours that have developed around film spectatorship and cinema's status as an elitist versus popular cultural form?

The Rocky Horror Picture Show premiered in America on September $24^{\text {th }} 1975$ to public indifference. However, six months later it began screening at midnight in Greenwich Village, New York City. A unique relationship between the 'outsider' movie audience emerged, the crux of which was the phenomenon of 'talking back' to the dialogue and 'singing along' to the songs. The barrier between audience and screen began to further breakdown as the film gained subcultural popularity through dress-up, theatrical enactment, the use of props and ironic audience interplay. For Raymond Knapp Rocky Horror became, "a cult based folklike process" evolving "an oral tradition that both hardened into ritual and, paradoxically, liberated its participants into a quasi-improvisatory space" $(2009,242)$. How do the performative aspects Rocky Horror Picture Show suggest alternative pleasures of spectatorship that transgress 'accepted' notion of cinematic spectatorship?

In 2013 Dutch filmmaker Bobby Boermans release interactive horror film APP. The film brought the now commonplace practice in home-viewing of 'second-screening' to cinemas by creating mobile phone software that syncs with the film's audio track giving audiences additional information designed to create another level of immersion. H. Shaw Williams writing for Screenrant.com raises concerns: "the most 
obvious of which is that audience members cannot simultaneously look at both their phone screen and the big screen, so checking out the latest bonus material on the former will inevitably mean missing the action on the latter" $\left(3^{\text {rd }}\right.$ December 2013). The arrival of mobile technologies, social media and second-screening has been adopted almost organically in the context of television but what are the further implications, for both producers and consumers, when such technologies encroach into the sacrosanct space of the auditorium?

The latest incarnation of Secret Cinema took place in the summer of 2015 featuring The Empire Strikes Back (Kershner, 1980) as the basis for their most ambitious theatrical expansion of a film text to date. Secret Cinema, developed by Fabian Riggall, creates theatrical expansions of new and classic films that rely on social networking for clandestine marketing with the tag line "tell no one". The notion of a secret group of cineastes converging on an unknown location to view an unnamed film reflected an anti-mainstream sensibility that arguably reinvigorates the cultural cache of cinema as an event. However, the success of Secret Cinema has led to happenings that have hugely expanded in scope with the 2014 theme park construction around Back to the Future (Zemeckis, 1985) and now The Empire Strikes Back. For Sarah Atkinson, "The Secret Cinema experience is proving to be a popular way of experiencing film, espoused by its followers, unmooring assumptions relating to the fading popularity of cinema (in favour of online, on-demand modalities), and one which audience members seem willing to pay a premium for" $(2014,48)$. Does the popularity of Secret Cinema and its imbrication of immersive theatricality symbolise a lost yearning for cinema as an embodied, collective, social experience?

The examples cited above are evidence of the paradoxes and tensions in defining the relationship between film text and audience that have always existed but have perhaps been hidden behind the hegemonic definition of cinema. The economic structuring of film consumption and the emergence of film criticism and academic film study have set certain expectations which govern the experience of film-going and film-viewing. The defined space of the cinema auditorium, which anchors a specific relationship between projector, screen and spectator, has been the bedrock of the film industry and, in turn, the socio-cultural grounding of cinema as the preeminent medium of the 
$20^{\text {th }}$ century. Cinema's environmental architecture also imbues a specific discipline of watching: the darkened space, the hushed, concentrated audience sitting motionless and captivated by the series of still images projected at 24 frames a second giving the illusion of movement, facilities the fully immersive experience that is cinema.

The experience has been afforded a unique, perhaps even mythic status, through the emergence of cinephilia and film studies. The concept of the 'cinematic dispositif', developed by film philosophers such as Jean-Louis Baudry (1975), Gilles Deleuze (1992) Raymond Bellour (2000), theorises the effect of the technological apparatus combined with the spatial architecture, creating a homogenous perspective in relation to the film text. This dispositif therefore becomes a kind of metaphysical anchoring point for discussions regarding the relationship between spectator and film. Indeed, when the conditions of cinematic experience became socio-culturally fixed - perhaps from the sound era to the late 1950s - then arguments begun over the effect of films on spectators. The stability of the conditions of film viewing, along with the assumption of a synthesis between the textual parameters of film and the contextual parameters of the theatre, results in a tendency to collapse cinema and film into each other. Film scholarship has often conflated cinema and film or understood film as enacted largely through cinema exhibition, whether in the close analysis of film texts and their hypothesised unconscious operations or in the emphasis on imagined practices of spectatorship over actual audiences (see, for example, the studies of Hitchcock's films in the context of theatrical spectatorship by those such as Cowie, 1993; Doane, 1991; Modleski, 2005).

Although the majority of academic interrogation continues to focus of the primacy of film text there is a range of work that accounts for the diverse set of histories and practices of audience engagement that do not conform to the hegemonic dispositif. Most obviously the studies of the history of early cinema suggest less a fixed practice of spectatorship and more a range of spatial practices mobilised around a screen image (Gunning, 1986; Friedberg, 1993). There are strands of analysis that explore how cinema exhibition and experiences are as much embedded in ritual, cultural and geographic circumstances as they are in broader institutional or commercial ones (Hansen, 1991; Stokes and Maltby, 1999). Throughout history audience experiences 
have been transformed by technologies (Manovich, 2001; Acland, 2003; Jancovich et al 2003) and the cinema has been utilised as a space of experimentation whether in artistic or commercial practice (Shaw and Weibel, 2003; Marchessault and Lord, 2007; Bellour, 2013; Rogers, 2014). Theories of spectatorship have developed in relation to a presumed set of dominant cinema theatre conventions and conditions (including screen size, auditorium architecture, lighting conditions, audience noninteraction). However, given the continued technological and experiential transformations of cinema, such theories have necessitated revision or repositioning (Metz, 1982; Belton, 1992; Sobchack, 1992).

At the end of the $20^{\text {th }}$ century the transformational effects of what might loosely called be digital culture, has revolutionised mediated engagement with the world. The speed of technological change has resulted in an amorphous ecosystem of interaction where the constitution of what an audience is and what it does has become almost impossible to taxonomise, regulate or predict. The effect on cinema industrially, technologically, economically, artistically and experientially has certainly garnered a good deal of cultural pessimism, particularly from those who hold on to the cinematic dispositif as ideal. Not to mention consternation from the film industry which has had to look at new economic models and accept that cinema is no longer the primary cite for film spectatorship.

In academic parlance the concepts of convergence and interactivity characterise a multiplicity of audience practices that utilise a symbiosis of old and new media. Indeed the very concept of spectatorship and/or audience 'practice' is troubling accepted tenets of the cinematic dispositif. In the broad context of digital culture what may have been considered anomalous, disruptive, ruptures of the cinematic norm are now much more pervasive to the point that they becoming integrated in production, distribution and exhibition structures more formally. The corollary of this is that the discipline of film studies is undergoing a moment of existential crisis in which the accepted methodologies and theoretical models may no longer apply. In many ways there is a fissure between assumptions about standard auditorium viewing and acceptance of the huge range of experiences and practices undertaken. 
A growing body of work however, has begun to interrogate current cinematic zeitgeist from an interdisciplinary range of entry points. Indeed, much of this research deals with, directly or by implication, transformational aspects of cinematic space and spectator engagement. This includes broad contextual explorations of the multifaceted implications of digital technology on cinema (Keane 2007; Tryon, 2009; Rombes, 2009); fandom and new fan practice (Shefrin, 2004; Christie, 2012); new conceptions of the interactive audience (Cover, 2006; Hesselberth, 2014); the overlapping of cinematic space with contemporary art spaces (Parante \& de Carvalho, 2008; Patenburg, 2012;); and theorisations that look to expand the understanding of cinema in light of digital transformations (Iordanova \& Cunningham, 2012; Atkinson, 2014). This special edition of Networked Knowledge is informed by, and contributes to, this work addressing questions of cinematic space and audience practice in the context of the digital age.

The articles in this issue speak to some on-going and current debates and practice related to cinema and film ranging from cinephilia to multiscreen art installations. The articles consider the expansion of cinema experiences into other locations and on other devices. Cinema is considered holistically as technology, space, experience and form. New and emerging technologies inform much of the current thinking about cinema, not only those technologies of exhibition and film form, but also those related to wider communication practices. Indeed the culture of cinema and film- the sharing of information around them, as well as the experiences that might compete with themare as significant as any other. Rather than consider cinema and film as challenged by emerging technologies, experiences or practices, these articles propose an expanding outwards: to the streets where live events or performances draw the pleasures of the screen out into the world; to multiscreen projection and the narrative 'play' enabled by such; to the re-emergence of cinephilia through memory of cinema-going; and, finally, to digital platforms that enhance and revitalise the cinema as pleasurable experience.

Elliot Nikdel's article 'Re-centering the Cinema Experience in a Multi-Platform, Digital Age' considers the socio-historical definitions and interrogations of cinema as spatial environment. He re-explores Baudry's notion of the dispositif, the unique 
experience created by architecture and apparatus of cinema, and explores how the standardisation of this spectatorship practice grounds both the economics of the film industry but also gave rise to cinephilia pre-occupation with filmic text. Furthermore, Nikdel explores how the arrival of alternative mechanisms of consuming films threaten cinema's hegemony with suggesting that multi-platform streaming just one in a long line of examples. He suggests however that such challenges do not spell the end of cinema as many have predicted.

In 'New Materialist Spectatorship: the Moving-Image-Body, the Mockumentary and a New Image of Thought', Miriam von Schantz proposes a rethinking of spectatorship through an engagement with new materialist theory. She troubles the rigid demarcation of spectator and film text arguing that the act of watching is productive of what she defines as the moving-image-body. Drawing from Deleuze, and using the genre of mockumentary, she discusses the production of new realities through a methodological proposal that attempts to map, not what the event of spectating means, but rather what it does.

Elspeth Mitchell's 'In Excess, Elswhere and Otherwise: Feminie Subjectivity in EijaLiisa Ahtila's multi-screen installation If 6 Was 9' (1995) deploys the feminist philosophy of Luce Irigaray theorising the audio-visual installations of Finnish artist, Eija-Liisa Ahtila. Ahtila's work interrogates feminine desire and subjectivity by utilising multiple viewing positions in a spatial architecture designed to disrupt the accepted relation between projector, screen and viewer. Mitchell makes parallels between Luce Irigaray's concept of 'Elsewhere' and Ahtila's audiovisual installation If 6 Was 9 (Jos 6 olis 9, 1995) to explore the exclusion inherent in feminine representation. For Mitchell the form and content of the multi-screen installation produces and disrupts traditional cinematic representation in order to highlight and explore sexuality, desire and subjectivity from a feminist standpoint.

Shanaz Shakir's 'A Social Zombie: The Performative Nature of Contemporary (British) Zombie Cinema Fandom' asserts that the performance of Zombie fandom has deployed digital technologies to extend the spatial, experiential and interactive understanding of horror cinema. In particular the focus on theatrical enactment and 
the creation of zombie identities can be seen as a new layer of cinematic immersion and interactive play. In a self-reflexive analysis Shakir interrogates combat-ops-UK's airsofting (paintball, without the paint) event The Hungry Games, in which she performed various aspects of zombification. This is used as a platform for which to explore new pleasures (and terrors) of active performance and postulate how fan performance offers a potential redefinition of horror cinema experience.

This special edition of Network Knowledge concludes with a transcribed interview conducted by one of the editors, Dr Dario Llinares talking to Dr Sarah Atkinson. Atkinson is the author of Beyond the Screen: Emerging Cinema and Engaging Audiences, which looks to expand the conceptualisation of cinema in light of the digitally networked society. She analyses a series of case studies that reflect new forms of cinematic engagement, consumption, interactivity and play arguing that the traditional auditorium is just one location among many which can now be constituted as cinema. Llinares and Atkinson discuss many of the themes prevalent in the articles of this special edition and postulate as to the potential crisis in traditional definitions of cinema and how attendant issues could be addressed in Film Studies.

Rather than propose this collection of articles as a new development in cinema and film, one might more appropriately place it within the history of interventions, contestations, and rethinking of spatial practices of film viewing and the experience of the cinema. No doubt, fundamental ideas of cinema and film remain, despite the continued re-articulation, experimentation and play with both. The on-goingness of cinema and film as concepts, as institutional terms and as activities reflects the persistence of both as successful and pleasurable experiences and forms. But undoubtedly we have entered an era where the spatial and spectatorial pleasures of the cinematic cannot be easily contained.

\section{References}

Acland, C. R. (2003) Screen Traffic: Movies, Multiplexes and Global Culture, Durham, NC: Duke University Press. 
Atkinson, S. (2014) Beyond the Screen: Emerging Cinema and Engaging Audiences, London: Bloomsbury.

Baudry, J-L. (1975) 'Ideological Effects of the Basic Cinema Apparatus', Film Quarterly, 28, 2, 39-47

Belton, J. 1992. Widescreen Cinema. Cambridge: Harvard University Press.

Bellour, R. (2000) 'La querelle des dispositifs', Art Press, 262.

Bellour, R. (2013) '“Cinema, Alone"/Multiple "Cinemas"', Alphaville: Journal of Film and Screen Media 5 (Summer). [online] Available at http://www.alphavillejournal.com/lssue5/HTML/ArticleBellour.html. Accessed 3 August 2015.

Christie, I. (ed). (2012). Audience: Defining and Researching Screen Entertainment Reception, Amsterdam: Amsterdam University Press.

Cover, R. (2006) 'Audience inter/active: Interactive media, narrative control and reconceiving audience history', New Media \& Society, 8, 1, 139-158.

Cowie, E. (1993) 'From Fantasia', in Easthope, A. (ed) Contemporary Film Theory, New York: Longman pp147-161

Deleuze, G. (1992) 'What is a dispositif?', in Armstrong, T. J. (ed) Michel Foucault Philosopher, New York: Routledge.

Doane, M. A. (1991) Femmes Fatales: Feminism, Film Theory, Psychoanalysis, New York: Routledge.

Friedberg, A. (1993) Window Shopping: Cinema and the Postmodern, Berkeley: University of California Press. 
Gunning, T. (1986) 'The Cinema of Attraction: Early Film, Its Spectator and the Avant-Garde', Wide Angle. 8, 3-4.

Hansen, M. (1991) Babel and Babylon: Spectatorship in American Silent Cinema, Cambridge: Harvard University Press.

Hesselberth, P. (2014) Cinematic Chronotopes: Here, Now, Me, New York \& London: Bloomsbury.

Iordanova, D. \& Cunningham, S. (2012) Digital Disruption: Cinema Moves OnLine, St Andrews: St Andrews Film Studies.

Jancovich, M., Faire, L. \& Stubbings, S. (2003) The Place of the Audience: Cultural Geographies of Film Consumption, London BFI/Palgrave Macmillan

Keane, S. (2007) CineTech: Film, Convergence and New Media, Basingstoke: Palgrave

Knapp, R. (2009) American Musical and the Performance of Personal Identity, New Jersey: Princeton university press.

Manovich, L. (2001) The Language of New Media, MA: MIT Press.

Marchessault, J. \& Lord, S. (eds) (2007) Fluid Screens, Expanded Cinema, Toronto: University of Toronto Press.

Metz, C. (1982) The Imaginary Signifier: Psychoanalysis and the Cinema, Bloomington: Indiana University Press.

Modleski, T. (2005) The Women Who Knew Too Much: Hitchcock and Feminist Theory, New York \& Oxon: Routledge. 
Pantenburg, V. (2012) '1970 and Beyond. Experimental Cinema and Art Spaces', in Koch, G., Pantenburg, V., \& Rothöhler, S. (eds) Screen Dynamics: Mapping the Borders of Cinema, Neubaugasse: Synema. pp.78-92.

Parante, A. \& de Carvalho, V. (2008) 'Cinema as Dispositif: Between Cinema and Contemporary Art', Cinémas : revue d'études cinématographiques / Cinémas: Journal of Film Studies. 19,1. 37-55.

Rogers, A. (2013) Cinematic Appeals: The Experience of New Movie Technologies, Chichester, West Sussex: Columbia University Press.

Rombes, N. (2009) Cinema in the Digital Age, New York: Wallflower Press.

Shaw-Williams. H. (2013) New Interactive Horror Movie 'App' Enhanced by Audience Cell Phones [Internet] http://screenrant.com/app-interactive-horrormovie-cell-phone/

Shaw, J. \& Weibel, P. (2003) Future Cinema: The Cinematic Imaginary After Film, Cambridge, Mass. London: MIT press.

Shefrin, E. (2004) 'Lord of the Rings, Star Wars and Participatory Fandom: Mapping New Congruencies between the Internet and Media Entertainment Culture'. Critical Studies in Media Communication. 21,3. 261-281

Sobchack, V. (1992) The Address of the Eye: The Phenomenology of Film Experience, New Jersey: Princeton University Press.

Stokes, M \& Maltby, R. (eds) (1999) American Movie Audiences: From the Turn of the Century to the Early Sound Era, London: BFI.

Tryon, C. (2009) Reinventing Cinema: Movies in the Age of Digital Convergence, New Brunswick, NJ: Rutgers University Press. 
Unknown Author (1930) 'Cinema Audiences-What is Wrong?- Managers

View', Chelmsford Chronicle, Friday $23^{\text {rd }}$ May.

Unknown Author, 1937. 'Noisy Cinema Audiences.' Portsmouth Evening

News, Wednesday 28 April.

Dr Dario Llinares is Principle Lecturer in Contemporary Screen Media at the University of Brighton. He is currently researching the potential implication of modes of interactive spectatorship and their effect on auditorium viewing. He is examining the necessity for interdisciplinary methodologies to analyse film engagement and exploring the potential philosophical reframing of cinema in the context of the digital age. He has previously published research on masculinity, media and postmodernity, time-travel in film, the astronaut as a cultural icon and he is the co-presenter and producer of The Cinematologists podcast.

Email: D.Llinares@brighton.ac.uk

Dr Sarah Arnold is Senior Lecturer in Film and Television at Falmouth University. She is currently working on the book Television, Technology and Gender: New Platforms and New Audiences for I.B. Tauris. Her previous books include Maternal Horror Film: Melodrama and Motherhood (Palgrave) and the co-authored book The Film Handbook (Routledge). Her research focuses on viewing spaces and environments of, and within, television and film.

Email: sarah.arnold@falmouth.ac.uk 